\title{
Restoration of White Pine in Minnesota, Wisconsin, and Michigan
}

M.E. O stry

Additional INDEX words. R ibes, disease resistance, tree improvement, Cronarti um ribicola, Pinusstrobus

Summary. White pine blister rust (C ronarti um ribicola J.C. Fisch.) (WPBR) was discovered on R ibesL. in N ew York in 1906, although it was accidentally introduced from E urope on pine (PinusL.) seedlings. The spread of this destructive fungus has changed the forests in $\mathrm{N}$ orth America. After decades of reduced planting because of the concern over the impact of WPBR, white pine (PinusstrobusL.) is now being restored in the lake states of M innesota, Wisconsin and M ichigan. Although the potential for growing white pine is high on many sites, the disappearance of a seed source because of logging and fires means that reestablishment of white pine to these areas will require active management. A series of plantings have been established on three national forests in M innesota and M ichigan to evaluate various silvicultural treatments intended to minimize the incidence of WPBR and to compare the performance of seedlings selected for disease resistance to nonselected planting stock.

T

he WPBR fungus is a long cycle, heteroecious rust that produces five types of spores and requires two hosts, alternating between five-needle pines and currants or gooseberries ( $R$ ibes $L$ ). Attempts to control this disease were the most extensive in time, labor and money in the history of forestry in the $U$ nited States ( $M$ aloy 1997). Exacting moisture and temperature conditions are required for spore dispersal, germination, and infection of the two hosts by the various spores, and management strategies to avoid infection are based on these conditions (Van Arsdel, 1961). L ocal environmental conditions can influence WPBR incidence within rust hazard zones and may also have played a role in the effectiveness of local R i bes eradication efforts (R obbins and Jackson, 1988; O strofsky et al., 1988).

\section{Materials and methods}

Since 1989, a total of six research/ demonstration plantings consisting of more than 5,000 trees have been established on the $\mathrm{H}$ iawatha $\mathrm{N}$ ational Forest (NF) (1989), Chippewa N F (1998), and Superior N F $(1997,1999)$ in M ichigan and $M$ innesota in areas of moderate to high risk for WPBR. White pine seedlings selected for resistance and good tree form and nonselected nursery seedlings are being screened under field conditions. We are comparing tree survival, pest incidence, and growth of seedling stock from the genetic improvement program of the U SD A Forest Service in the lake states and stock from the former M innesota Q uetico-Superior Research Center to nonselected nursery stock in replicated plantings across a range of site conditions.

Research plant pathologist, U SD A Forest Service, N orth C entral Research Station, 1992 Folwell Ave., St. Paul, M N 55108.

This research is being conducted in partnership with many individuals on the H iawatha, Chippewa, and Superior $\mathrm{N}$ ational Forests, and with forest health protection specialists with $\mathrm{N}$ ortheastern A rea State and Private Forestry, St.

Paul, M inn. Appreciation is extended to K. Ward, R. Giblin, and L. H augen for their assistance in data collection.

The cost of publishing this paper was defrayed in part by the payment of page charges. U nder postal regulations, this paper therefore must be hereby marked advertisement solely to indicate this fact. 
Table 1. White pine height growth and blister rust (WPBR) incidence in the $1989 \mathrm{H}$ iawatha $\mathrm{N}$ ational Forest planting, June 1999.

\begin{tabular}{lcccc}
\hline Treatment & $\begin{array}{c}\text { Live trees } \\
\text { [no. (\%)] }\end{array}$ & $\begin{array}{c}\text { M ean ht } \\
{[\mathbf{f t}(\mathbf{m}) \mathbf{]}}\end{array}$ & $\begin{array}{c}\text { Infected trees } \\
\text { [no. (\%)] }\end{array}$ & $\begin{array}{c}\text { W PBR cankers } \\
\text { (no.) }\end{array}$ \\
\hline Clearcut & $347(58)$ & $7.8(3.2)^{z}$ & $20(5.8)^{\mathrm{y}}$ & 39 \\
Shelterwood & $445(74)$ & $5.7(2.3)$ & $48(10.8)$ & 69 \\
N onselected stock & $401(67)$ & $6.0(2.4)^{z}$ & $46(11.5)^{z}$ & $66^{y}$ \\
Selected stock & $391(65)$ & $7.2(2.9)$ & $22(5.6)$ & 42 \\
U npruned & $403(67)$ & $6.7(2.7)$ & $43(10.7)^{\mathrm{x}}$ & $83^{z}$ \\
Pruned & $389(65)$ & $6.5(2.7)$ & $25(6.4)$ & 25 \\
\hline
\end{tabular}

zP $=0.005$.

$\mathrm{yP}=0.025$

$\mathrm{xP}=0.05$

Treatments being compared include1) growing whitepine in clearcuts vs. under a recommended shelterwood to minimize conditions conducive for WPBR infection and attack by white pine weevils [Pi ssodesstrobi (Peck)] and 2) pruning to remove lower branches most susceptible to WPBR plus corrective pruning for weevil-attacked trees (Katovich and M ielke, 1993). I ncreased shade under the closed canopy of a shelterwood may also suppress the growth of R ibeswithin astand (Stewart, 1957).

The planting sites include paired clearcut and shelterwood treatments in a northern hardwood stand and in a paper birch (Betula papyrifera M arsh.) stand; a trembling aspen (Populus tremuloidesM ichx.) clearcut; and in small clearcuts in three mixed-conifer stands. Theeffects of different level sof competing vegetation on various ecological land types (ELTs) on tree growth and pest incidence are also being examined. Tree survival, heights, and incidence of damage from biotic and abiotic agents are recorded yearly.

The goal of this study is to determine best management practices for restoring white pine on various ELTS using silvicultural strategies and genetic improvement to minimize damage caused by WPBR, white pineweevil and browsing by white-tailed deer [O docoileusvirginianus (Boddaert)].

\section{Results and discussion}

The early results on the $\mathrm{H}$ iawatha N F sitein M ichigan clearly showed that white pine height growth is greater but survival is lower in the clearcut treatment compared with trees in the shelterwood (Table 1), and the incidence of white pine weevil attack was greater ( $4.1 \%$ vs. $1.6 \%)$. U nexpectedly, WPBR incidence has been significantly greater in the shelterwood treatment.
H owever, the majority of infected trees were in one plot nearest to the native $R$ ibesgrowing on the site. WPBR cankerson themain stems of several pruned trees resulted from infection of needles directly attached to the bole, however, significantly fewer pruned trees are infected and they have significantly fewer cankers than the unpruned trees (T able 1). T reesfrom theU SD A Forest Service improvement program weresignificantly taller and there were significantly fewer infected trees across all the treatments than the nonselected trees (Table 1 ). Armillariaroot rot caused byA rmillaria (Fr.:Fr.) Staude has killed more trees in the northern hardwood clearcut treatment $(5.5 \%)$ than in the shelterwood (3.1\%). H eavy snow and ice and extremely cold weather have also severely damaged trees at the M ichigan site.

Although it is too early for meaningful results from the $M$ innesota sites, afew trends have become evident. D eer browsing has been severe at one of the sites on the Superior N F in M innesota, requiring replanting of theplotsand use of a protective bud-capping technique (stapling afolded piece of paper over the terminals) each fall to prevent damage to the terminal buds. Growing white pine in areas of high deer populations will requiremanagement to avoid planting failuresasa result of heavy browsing. Competing vegetation, especially on the mesic sites will require much more effort to successfully establish white pine than on drier, nutrient-poor sites. In addition, since white pine is resistant to the shoot blight disease of understory red pine (Pinusresinosa Ait.) (O stry et al., 1990), planting white pine under a red pinecanopy will enablemanagersto maintain a conifer component on these sites.

Given the biological and economical restraints of restoring white pine using artificial regeneration techniques, we need to use silvicultural strategies and target sites that provide the optimum potential for success. Geographic location, topography, stand structure, soil, and climate are major factors that need to be considered when selecting planting sites for white pine and in managing this species to avoid damage from WPBR, white pine weevil, and deer. Successful restoration of white pine will require a sustained commitment to intensive management. The research described in this report is designed to serve as operational demonstrations to assist land managers in selecting the best prescription for establishing and growing white pine under their set of conditions.

\section{Literature cited}

Katovich, S. and M. M ielke. 1993. H ow to manage eastern white pine to minimize damage from blister rust and white pine weevil. U SD A For. Serv. N .E. AreaStatePrivateFor. NA-FR-01-93.

Maloy, O.C. 1997. White pine blister rust control in North America: A case history. Annu. Rev. Phytopathol. 35:87-109.

O strofsky, W.D ., T. Rumpf, D. Struble, and R. Bradbury. 1988. I ncidence of white pine blister rust in $M$ aine after 70 years of a $R$ ibes eradication program. Plant D is. 72:967-970.

O stry, M .E., T.H . N icholls, and D .D . Skilling. 1990. Biology and control of sirococcusshoot blight on red pine. U SD A For. Serv. N.C. For. Expt. Station Res. Paper N C-295.

Robbins, K. and W.A. Jackson. 1988. White pine blister rust in the eastern upper peninsula of M ichigan. N .J. Appl. For. 5:263-264.

Stewart, D.M. 1957. Factors affecting local control of white pine blister rust in $M$ innesota. J. For. 55:832-837.

Van Arsdel, E.P. 1961. Growing white pine in the lake states to avoid blister rust. U SD A For. Serv. Lake States For. Expt. Sta. Paper 92. 